\title{
CFRP 複合材およびェポキシ樹脂の高温における弾性係数
}

\author{
石 川隆 司*, 小山一夫**, 小林 繁 夫***
}

(1978年 4 月 11 日受付)

\author{
Elastic Moduli of CFRP-Composite and Epoxy-Resin at \\ High Temperature \\ T. IsHIKAWA,* K. KoYAMA** and S. KobAYASHI*** \\ (Received April 11, 1978)
}

\begin{abstract}
In the temperature range from room temperature to the glass-transition point $\left(T_{g}\right)$ of matrix, elastic moduli of CFRP-UD composites, CFRP-FW cylinders and Epoxy resin are measured. An electro-optical extensometer, Zimmer model $200 \mathrm{X}$, is used in these experiments. Experimental results of $E_{x}$ are compared with the numerical results by the authors' computer program based on measured data for Epoxy and an agreement is very good. Temperature dependency of $E_{x}$ is directly influenced by that of $E_{m}$, but $E_{z}$ is almost independent of $E_{m}$. It should be noted that $\nu_{m}$ has considerable effect on $E_{x}$, particularly at near $T_{g}$ point. Curing temperature history changes trends of temperature dependency of $E_{m}$ at most Epoxy.
\end{abstract}

\section{1. 緒言}

常温から，マトリックスのガラス転移点温度 $\left(T_{g}\right)$ を 越す程度の高温に至るまでの複合材とマトリックスの弾 性係数を知ることは, いくつかの点で工学的な重要性を もっている．たとえば，第 1 は複合材料の使用温度範囲 の拻大に対処するため，第 2 にはこの情報と熱膨脹俰数 の情報がないと積層複合材の内部熱残留応力を評価でさ ないこと，などをあげることができる、しかしながら， これまで正確な定量的測定はあまり行なわれていない． この原因は，主として高温に扣ける歪測定の困難さ，と くに弾性係数の小さいときに歪ゲージを用いるさいの補 強効果, あるいは温度補償といった点が克服されていな いことにあったものと考兄らる。

* 航空宇宙技術研究所技官 (182 調布市深大寺 町 1880)

Research Engineer, National Aerospace Laboratory, 1880, Jindaiji-machi, Chofu 182, Japan

**, *** 東京大学工学部航空学科 (113 東京都文京区 本郷 7-3-1)

Dept. of Aeronautics, University of Tokyo, 7-3-1, Hongo, Bunkyo-ku, Tokyo 113, Japan

** 助手 Research Fellow, *** 教授 Professor
そこで著者らは，非接触電子光学式歪測定装置を用い て，エポキシ樹脂，一方向 CFRP 材， CFRP-FW 円筒 の, この温度範囲における弾性係数を測定した. そして, 著者らの解析方法 ${ }^{1)}$ による理論值と比較することによ り，マトリックスの特性が，一方向材，積層材にどう反 映するかについて検討した. また，測定を行なわなかっ た一方向材の残りの独立な弾性係数の高温における值 を，著者らの解析方法により算出した.

\section{2. 実験}

\section{1 一方向材とエポキシの実験}

試験片の大部分には，かつて常温での弾性係数の測定 に用いた試験片（東レ(侏開発研究所にて作製; 文献 2 参 照）のらちの I 系列（off-axis 試験片でないもの）を再 び用いた. このI 系列の試験片の各群の形状, 寸法を Fig. 1 (a) に示した. 成形条件, $V_{f}$ 等の詳細は, 文献 2 の第 1 表, 第 2 表を参照されたい. そのあらましは, CFRP 材の $V_{f}$ はほぼ $65 \%$ であり, 樹脂は 828 エポ キシで，成形温度条件は Fig. 1 (c) に I-5，6，9 と付 記した時間-温度曲線で示されている. 一方向材の $E_{x}\left(=E_{T}\right)$ 測定用板状試験片が不足したので追加製作し た試験片を I-7 群, 高弾性樹脂 3130 エポキシの特性を 調べるための板状試験片をI-8 群と呼ぶ. いずれも東レ 


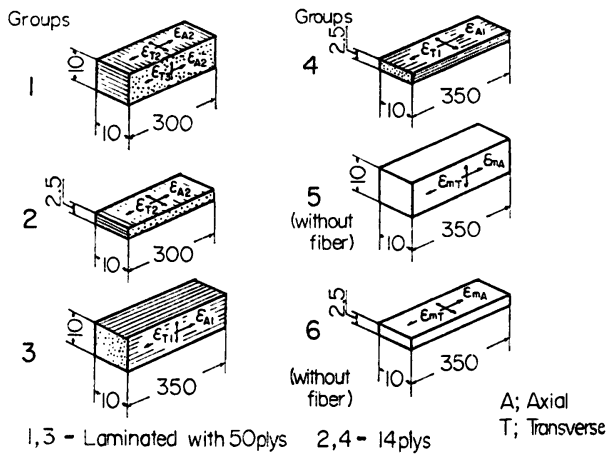

(a)

Fig. 1 (a) Dimension of specimens (Unit: $\mathrm{mm}$ ), (c) Temperature history at curing.

開発研で製作してもらった. それ以外にェポキシの $E_{m}$ の温度依存性測定用に自作した試験片を I-9, I-10 群と 名づける. これら追加試験片の形状, 寸法を Fig. 1 (b) に示した. I-9 群は I-5, 6 群と同一の成形温度条件で 作った板状および棒状試験片である．I-10 群は， $T_{g}$ 近 くでのポアソン比の挙動の測定用ならびに文献 3 の光弾 性実験用に，後硬化をせずに $T_{\boldsymbol{g}}$ を下げるように作った 試験片で，その成形条件の一例を Fig. 1 (c) に I-10-1 扣よび -2 の記号で示した. ポアンン比 $\nu_{m}$ 測定の際の 歪ゲージの補強効果をできるだけ減らすため板厚を厚く してある. 一部の試験片については実験後さらに $190^{\circ} \mathrm{C}$ 4 時間の追加後硬化を行なったあと, 再び実験を行なっ た.この履歷を Fig. 1 (c) に additional after cure と付記した線で示した。

実験装置としては, Instron TT-DM 型試験機に専用 佰温槽をセットしたものを用いた.この恒温槽はサイリ スタ回路を用いた温度制御装置を有し，温度精度は設定

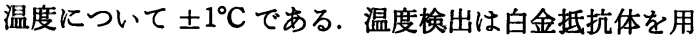
いている. 引張り試験の歪速度は, 一方向材とェポキシ の全温度範囲の全試験を通じて $3.3 \times 10^{-4} \mathrm{sec}^{-1}$ に統一

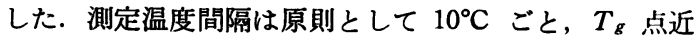

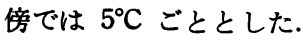

丕測定には, 電子光学式歪測定装置の一つである, 西 独 Zimmer 社製, Model $200 \mathrm{X}$ 型（使用レンズ 200-5; 標点距離 $75 \mathrm{~mm}$ ) を用いた. 歪の絶対值を正しく求める 必要のある $E_{m}, E_{x}, E_{2}$ の測定にはこの装置はきわめ て有効であって，この使用が，本実験の大きな特徵の一 つとなっている．佰温槽の空から直流電燈により試験片 のターゲットを照射し, 光軸に垂直なターゲット間の変 位差を出力電圧として, 荷重の值とともに $X-Y$ レコ一

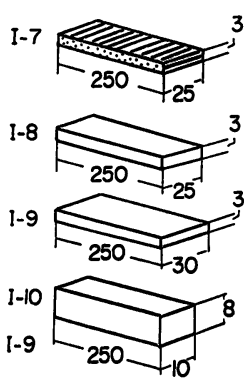

(b)

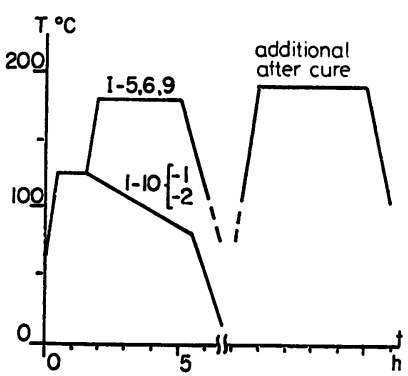

(c) (b) Dimension of additional specimens (Unit: $\mathrm{mm}$ ),

ダに記録した. ターゲットは黒色つや消しペイントと白 色けがき用ペイントを用いて塗り分けた. ヤング率の計 算には曲げの効果などによる初期不整域を越えたと考え られる荷重レベルの値を採用した。

ポアソン比の測定には高温用昰ゲージ（共和製, KFR2-C1-11）を用いた. 横歪の測定にはゲージレングスア ダプタを用いるなどして Zimmer を用いた測定も試み たが, 現状ではZimmerの大きさと個数の関係で同時に 縦横二つの歪を測ることができないため精度不良となる ので, 結局歪ゲージによる測定を採用した. ポアンン比 は昰の比であるから，ゲージの久点である補強効果なら びに温度効果が相殺されて精度よく測定されるものと考 えられる.この際の留意点としては, 高温用のゲージ, 接着剂, リード線を用い,ゲージ接着に細心の注意を払 ら必要がある. 高温用リード線を用いる場合には，抵抗 值 $R$ が大きい(ほぼ $7 \Omega / \mathrm{m})$ ので, ゲージファクタ $K$ を

$$
K_{A}=K R_{g} /\left(R_{g}+R_{l}\right)
$$

によって修正する必要がある．ここで $K_{A}$ は真のゲージ ファクタ, $R_{g}$ はゲージの抵抗， $R_{l}$ はリード線の抵抗で ある.ただし，このような配虑をしても，信頼性の高い 測定の上限は $T=130 \sim 150^{\circ} \mathrm{C}$ であると考えられる.

\subsection{CFRP-FW 円筒の実験}

フィラメントワィンディングで $60^{\circ}$ ヘリカル巻きと周 巻きの層の厚さの比が等しい円简を作り, Table 1 に示 す 3 種類の硬化条件により成形された 3 本の CFRP円筒 と，それに対応する硬化条件のエポキシ試験片について 前項に述べたと同様の引張り試験を行なった. これらの 試験片は住友電工侏で製作してもらった．試験片の寸法 等を Fig. 2 (a), (b) に示す. 円筒試験片の端末部は, 周巻き GFRP で補強してある. Fig. 3 に示すように 
Table 1 Curing conditions of CFRP-FW cylinder specimens $\left(\alpha_{W}=90^{\circ} ; 1 / 2\right.$ and $\left.\alpha_{W}=60^{\circ} ; 1 / 2\right)$.

\begin{tabular}{cll}
\hline Specimen & \multicolumn{1}{c}{ Cure } & After-cure \\
\hline A & $100^{\circ} \mathrm{C} 4 \mathrm{hr}$ & $135^{\circ} \mathrm{C} 5 \mathrm{hr}$ \\
B & $100^{\circ} \mathrm{C} 4 \mathrm{hr}$ & $170^{\circ} \mathrm{C} 5 \mathrm{hr}$ \\
C & $150^{\circ} \mathrm{C} 4 \mathrm{hr}$ & None \\
\hline
\end{tabular}

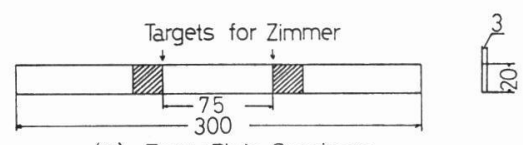

(a) Epoxy Plate Specimen

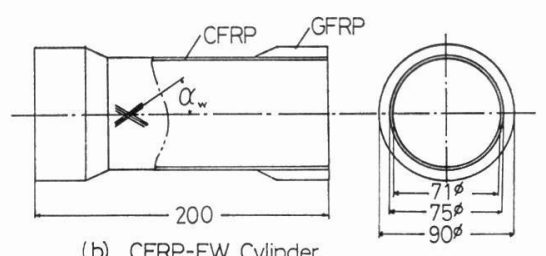

Fig. 2 Schematic views of CFRP-FW cylinders and corresponding epoxy specimens.

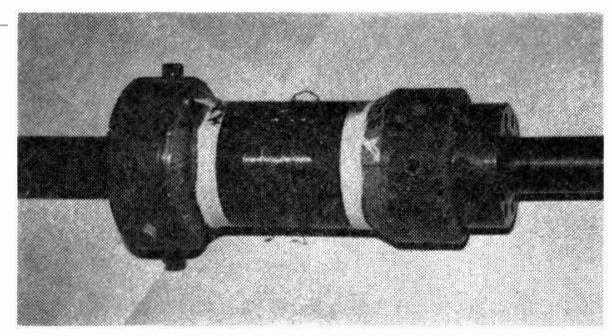

Fig. 3 FW cylinder specimen and fitting.

F W円筒内径と同じ外径の円筒部をもつ荷重用連結棒を 挿入し, 外側から8枚の円弧板を介し 8 本のボルトで連 結棒に固定した. 前項の実験と異なる点は, この実験の 際の歪速度が $3.0 \times 10^{-4} \mathrm{sec}^{-1}$ とやや小さくなっている ことのみである.

\section{3. 実験結果とその検討および数値計算結果との比較}

\section{1 エポキシ樹脂の結果}

エポキシ樹脂の弾性係数の測定結果を Fig. 4, 5 に 示す. Fig. 4 は $E_{m}$ と $T$ との関係であって, 太線が 成形後第 1 回目の実験結果，細線はその後同じ試験片に ついて追加後硬化（Fig. 1 (c) 参照）をしたあとの実験 結果である. 縦軸は対数目盛である. 828 エポキシ $\mathrm{BF}_{3}$ MEA 系のこの硬化条件 ${ }^{2)}$ による成形後第 1 回目では,

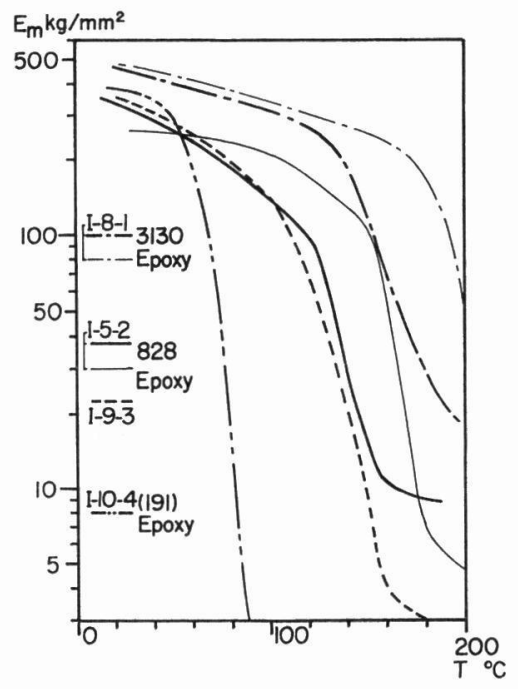

Fig. 4 Experimental results of $E_{m}$ for various epoxy specimens.

$T_{g}=130 \sim 140^{\circ} \mathrm{C}$ であり, $T_{g}$ 以下の温度領域での $E_{m}$ の温度依存性はかなり大きい,また, 東レ作製の試験片 (I-5-2) と, 自作の試験片（I-9-3）の差は大きくない. これはもちろん, 成形条件を類似させたからである. 高 弾性樹脂 3130 エポキシは常温で 828 エポキシの 1.3 1.4 倍の $E_{m}$ をもち $T_{g}$ の直前までかなり高い $E_{m}$ を もつ，良好な温度特性の樹脂であることがわかる． $T_{g}$ も $160^{\circ} \mathrm{C}$ 程度で, 828 エポキシより $20^{\circ} \mathrm{C}$ 近く高い。 た，比較のため行なった新樹脂 191 エポキシ（仮称）の 場合は, 常温の $E_{m}$ は大さいが $T_{g}$ は非常に低い.

同一の試験片での追加後硬化前と後とを比較すると, 828 エポキシの場合にはかなり $E_{m} \sim T$ 曲線の形に変化 が見られる.つまり, 追加後硬化後では常温の $E_{m}$ は追 加後硬化前の $3 / 4$ くらいに減少するが， $T_{g}$ 直前までの $E_{m}$ の減少の程度は少なく, $T_{g}$ は $20 \sim 30^{\circ} \mathrm{C}$ 上昇して いる. 常温の $E_{m}$ の減少の原因は必ずしも明らかでない が, 樹脂がむしろ劣化を起こしているという説せすある. このような傾向があるので, 追加後硬化前と後の $E_{m} \sim T$ 曲線を $T_{g}$ が一致するよらに重㸚あわせても二つの曲線 はよく一致しない. 3130 エポキシの場合には，追加後 硬化前と後では, $E_{m} \sim T$ 曲線の形そのものには変化が少 なく, 前者の曲線を $T_{g}$ が $40^{\circ} \mathrm{C}$ 程度上昇するよらにず らせると両者はよく一致する.

次に $\nu_{m}$ と $T$ の関係を $E_{m}$ の変化とあわせ示したも のが Fig. 5で, 太線が $\nu_{m}$, 細線が $E_{m}$ である. 歪ゲー ジを用いる関係上 $T_{g}$ を下げることを目的として, 828 


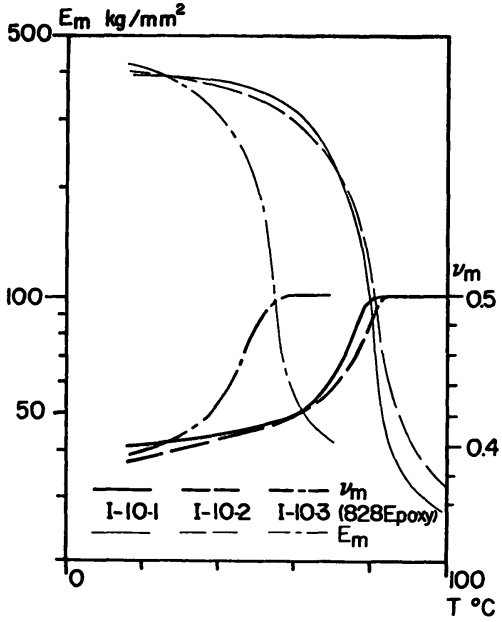

Fig. 5 Experimental results of $\nu_{m}$ for group I-10 epoxy specimens.

エポキシについて後硬化を行なわなかった I-10 群の試 験片についての結果を示す， $T_{g}$ の直前で $\nu_{m}$ が急激に 増大し, ほぼ $T_{g}$ のときに弾性体に拈ける上限值 $\nu_{m}=$ 0.5 に近ついていることが見られる. I-10-1，-2 と成形 温度履歴を変えた I-10-3 とでは, $T_{g}$ 点が $20^{\circ} \mathrm{C}$ 程度異 なっていることに正確に対応して $\nu_{m}$ が 0.5 に近づく 温度が異なっており， $\nu_{m} \sim T$ の関係がほぼ平行にシフ トしていることが見られる.このような $\nu_{m}$ のシフト現 象は，とうぜん予想されることであるが，これまでには， 必ずしも確認されていなかった。 ע $m$ は後述するように， $E_{x}, \nu_{x} y$ にかなり影響を与え, 熱膨脹係数 $\alpha_{x}$ にもやや 影響する（文献 5 ，第 7 図参照）ので，一方向材の材料 特性の温度依存性を議論するときには， $\nu_{m}$ の温度依存 性の傾向には十分注意する必要がある.

\subsection{CFRP 一方向材についての実験結果と数值計算} 結果

CFRP 材の $E_{x}$ 打よび $E_{z}$ の各温度に拈ける測定結果 を，上述のエポキシ材の測定値を用いて計算した理論値 とともに，それぞれ Fig. 6，7 および Fig. 8 に示し た. 继軸の $E_{x}, E_{m}$ は, 対数目盛である. Fig. 6 は 828 エポキシをマトリックスとした通常の成形条件の試験片 について追加後硬化を行なら前の, 2 点鎖線が板状, 1 点 鎖線が棒状試験片の結果である．点線が，緘維の弾性係 数 ${ }^{2)}$ は Table 2 の值を用い温度により変わらないとし て, 図中太実線で示した $E_{m}$ (Fig. 4 の太実線と同一) と細実線で示した $\nu_{m}$ を, 著者らの解析理論 ${ }^{1)}$ に基つくく 数值計算プログラムにインプットして得られた結果であ

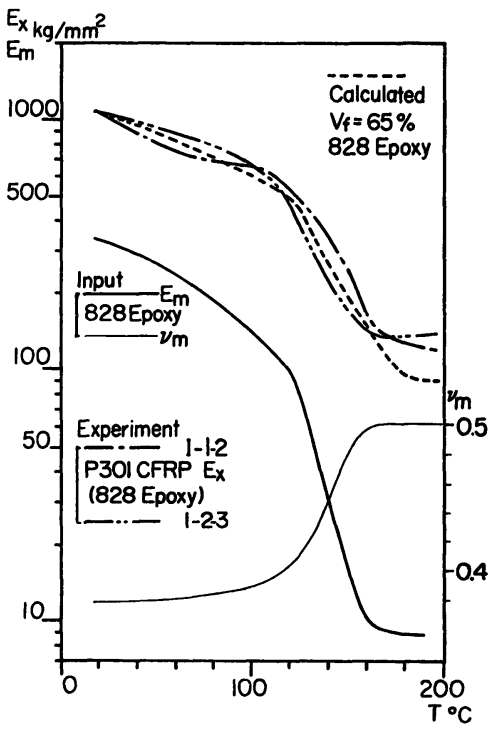

Fig. 6 Comparison between numerical and experimental results of $E_{x}\left(=E_{T}\right)$ for normally cured specimens.

Table 2 Elastic moduli of carbon fiber used in the present calculation.

$E_{f_{z}}=22,750 \mathrm{~kg} / \mathrm{mm}^{2}, \kappa=E_{f r} / E_{f z}=0.1, \nu_{f r z}=0.3$ $\nu_{f r \theta}=0.42, G_{f r_{2}}=2,540 \mathrm{~kg} / \mathrm{mm}^{2}$

る.一致はだいたい良好であるが，1 点鎖線のほうがよ り相対的な差が大きいことがわかる．これは，棒状試験 片のほうは厚さ方向に成形時の熱履歴が必ずしも一様で ないことと関連をむつと考えられる．付随的な事実とし て， $T_{g}$ を越した温度領域では一致の程度はよくないこ とがあげられる．この原因は必ずしも明確でない，一つ の可能な考え方として $T_{g}$ 近傍でマトリックスの粘弾性 特性が飛躍的に顕著になること，があげられる。また， 川端ら ${ }^{6)}$ は, 緎維近傍に一種の境界層の存在を仮定した 考え方を提案している.

Fig. 7 は，追加後硬化を行なって $T_{g}$ を上げた場合 の結果である. 図中 1 点鎖線が前図に 1 点鎖線で示した のと同じ試験片，図中 2 点鎖線が前図に 2 点鎖線で示し たのと同質と考えられる I-7 系列の試験片 (I-2-3 試験片 が破損したため)の追加後硬化後の結果である.太破線, 太点線は計算結果であって, $E_{m}$ としては両者とも, 図 中の細実線 (Fig. 4 細実線と同一; 追加後硬化後の結 果）を用い， $\nu_{m}$ としては図中のそれぞれ細点線, 細破 


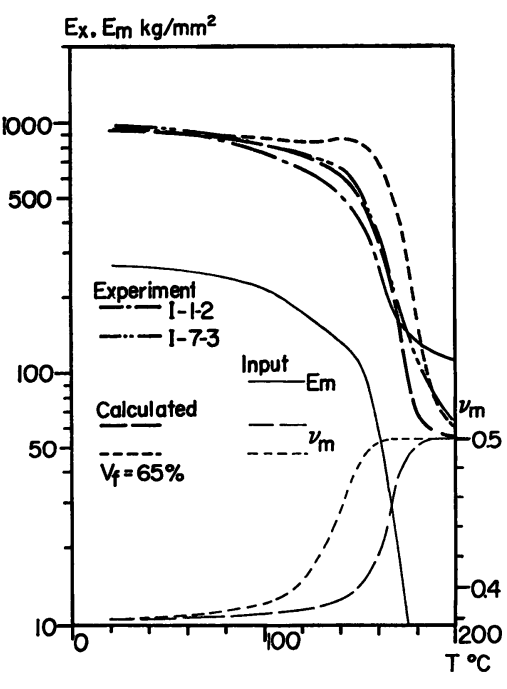

Fig. 7 Comparison between numerical and experimental results of $E_{x}$ for additionally after-cured specimens.

線を用いた結果（破線同士，実線同士は対応している） である. 細点線は Fig. 6 の $\nu_{m}$ と同じもの，細破線は $T_{g}$ の変動分だけこの曲線を平行移動させたものである. この眓から追加後硬化によるマトリックスの高温特性の 変動が，一方向材の $E_{x}$ のそれの变動を主として支配し ていること， $T_{g}$ 近くの $E_{x}$ の挙動を支配する因子とし て見落としてはならないのは $\nu_{m}$ であること，がわか る.つまり， $T_{g}$ の変動に伴った $\nu_{m}$ の変化を無視した 細点線のようなデータをインプットすると，太点線のよ らな実験値とかけ離れた $E_{x}$ の計算結果を得ることがわ かる. また追加後硬化後では常温の $E_{x}$ が $20 \%$ 弱減少 していることが見られる.

Fig. 8 は， $E_{z}$ に関して I-4 群の試験片の実験結果と 対応する計算結果の比較であって, $E_{f_{z}}=2.1 \times 10^{4} \mathrm{~kg} /$ $\mathrm{mm}^{2}$ としている. $E_{z}$ については複合則がなりたち， $E_{f_{z}} \gg E_{m}$ であるから， $E_{z}$ の変化はごくわずかであると 予想され，事実そうなっている．このことは，いい換兄 ると，この程度の温度範囲で $E_{f z}$ 一定とみなしてほぼさ しつかえないといってよいことになる。

実験的確認を行なわなかった一方向材の他の独立な弾 性係数 $G_{x z}, \nu_{x z}, \nu_{x y}$ の温度依存性について, Fig. 4 の太実線の $E_{m}$ と，それに対応する $\nu_{m}$ をインプット して得られた計算結果を, Fig. 9 には $G_{x z}$ を $E_{x}$ とあ わせて, Fig. 10 には $\nu_{x z}, \nu_{x y}$ を $E_{z}$ とあわせ示した. $G_{x z}$ はほほ $E_{x}$ と同様の曲線となる。 この $E_{x}$ は Fig. 6

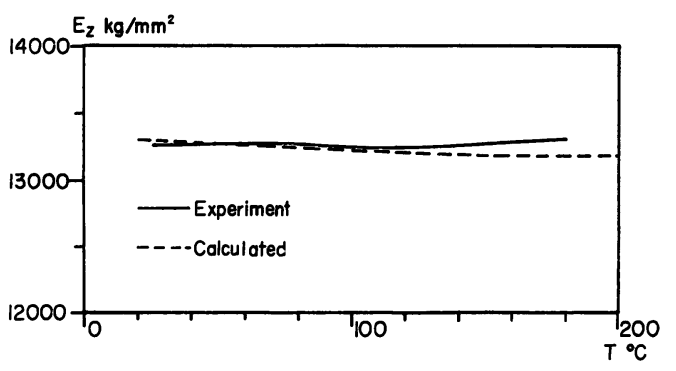

Fig. 8 Comparison between numerical and experimental results of $E_{z}\left(=E_{L}\right)$.

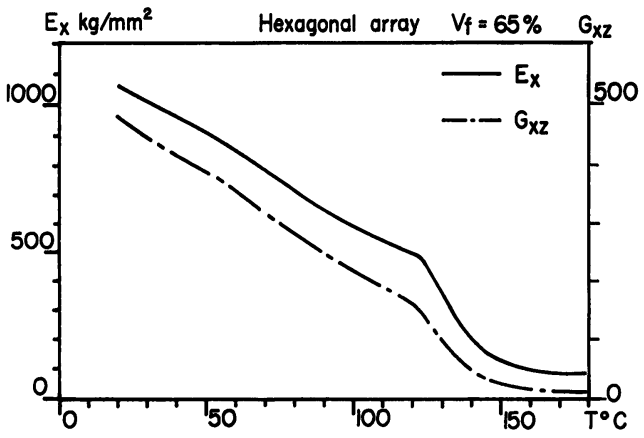

Fig. 9 Numerical results of $G_{x z}\left(=G_{L T}\right)$ with $E_{x}$.

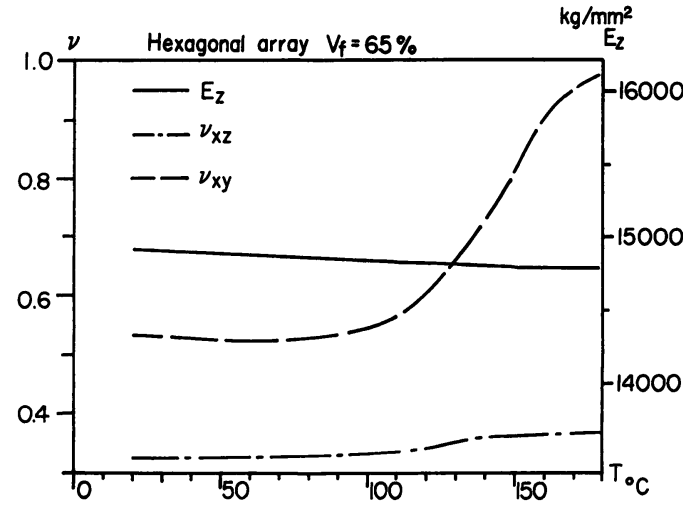

Fig. 10 Numerical results of $\nu_{x z}$ and $\nu_{x y}$ with $E_{2}$.

の太点線で描かれたものと同一の結果であって，縦軸を 等間隔目盛でプロットすると，このような曲線になる。 $\nu_{x z}$ は近似的に成立するポアソン比の複合則

$$
\nu_{x_{2}}=\nu_{f_{r 2}} V_{f}+\nu_{m}\left(1-V_{f}\right)
$$

にほぼ従って， $T_{g}$ 直前の $\nu_{m}$ のシフトに対応して小さ な変動を見せている．より大きく変化するのは $\nu_{x}$ であ 
って, $T_{\boldsymbol{g}}$ 直前から急增を始め, 最後は 1 に近づく。一 方向強化材のよ 5 な $x y$ 面内等方な弾性体の $\nu_{x y}$ の許容 される值の範囲は, 弾性係数マトリックスの正定值性か b

$$
-1 \leqq \nu_{x} \leqq 1-2 \nu_{x y}{ }^{2} E_{x} / E_{z}
$$

と導かれる7). CFRP 一方向材, とくにその高温時のよ らに $E_{z} \gg E_{x}$ のときは，(3)式の右辺は 1 に近づくので このような值が許容される. 試みに, Fig. 10 の $T=$ $140^{\circ} \mathrm{C}$ の $E_{x}$ 等を代入してみると上限值は 0.998 とな る.

\subsection{FW 円筒の実験結果と計算結果の比較}

$60^{\circ}$ ヘリカル巻き層 $1 / 2+$ 周巻き層 $1 / 2$ の $\mathrm{FW}$ 円筒の 実験結果と計算値との比較を Fig. 11 に示す.この円 筒に用いられた樹脂だけの実験結果は，3 種の成形条件 による $E_{m}$ にほとんど差がなかったので，図中細実線で 示した代表的な一例を採用した。これからまず著者らの 解析方法により一方向材の弾性係数を算出した．その結 果の一例として図中には $E_{x}$ を細破線で示した，次にこ れを用いて単純積層理論8) と基づいて，FW 円筒の軸方 向の平均弾性係数 $\left(E_{a}\right.$ と記す）を計算し, 実験結果と 比較したものである．両者はほぼ一致しているものと考 えられる，ただし，前節に述べたのと異なる点は，基礎 となる $E_{m}$ の特性に 3 種類の成形条件の違いが明確に現 われていないことを反映して，FW 円筒の実験結果にも 成形条件の差を明確に識別できるような傾向は見られな い.

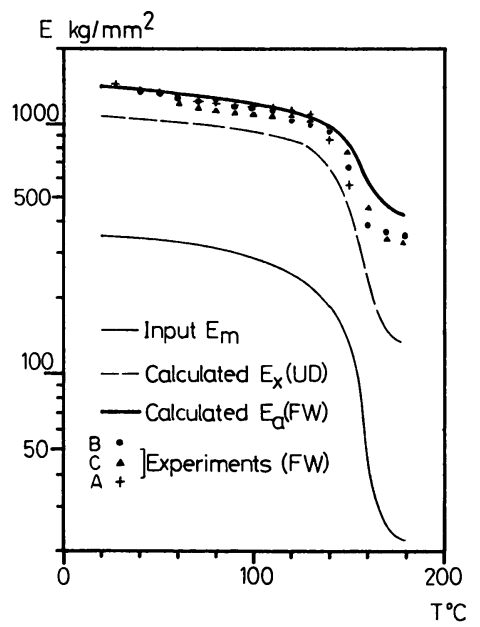

Fig. 11 Comparison between calculated and experimental results for CFRP-FW cylinder.

\section{4. 結 論}

CFRP 一方向材扰よびェポキシ樹脂の常温から $T_{g}$ を 越す程度の高温に至るまでの弾性俰数の值が, 従来より 正確に測定できたものと考える. 本研究の結果以下のよ らな結論が得られたものと考えられる.

（1） $E_{m}$ の温度依存性は, ほとんどの場合, 試験片の 受けた温度履歴に影響される. 828 エポキシの場合, 追 加後硬化を行ならと常温の弾性係数は減少するが, $T_{g}$ の直前までかなり大きな $E_{m}$ を維持する傾向にある.

(2) CFRP 一方向材の $E_{z}$ はほぼ一定であるが， $E_{x}$ はマトリックスの $T_{g}$ 点以下でもかなり減少し, $T_{g}$ 点 で急減する，そして，対応する温度履歷を与えた $E_{x}$ の 結果と， $E_{m}$ を代入した計算値とはよく一致し， $E_{x}$ の 温度依存性を主として支配するのは $E_{m}$ の温度依存性で あることが確認された。

(3) $T_{g}$ 点の直前で, マトリックスのポアソン比 $\nu_{m}$ は急激に 0.5 へと近づくことが確認された. この特性を 正確に把握しないと， $T_{g}$ 近傍での $E_{x}$ の值を正しく計 算できないことがわかった.

(4) $E_{m}, \nu_{m}$ の測定值を用いて計算した $G_{x z}, \nu_{x z}, \nu_{x y}$ の温度依存性は, $G_{x z}$ はほぼ $E_{x}$ に類似した変化をし， $\nu_{x z}$ はほぼ一定で $\nu_{m}$ の急変に対応して小さく急変し, $\nu_{x y}$ は $T_{g}$ 近傍で急增して 1 に近づくことが見いだされ た。

(5) $60^{\circ}$ ヘリカル巻き十周巻き FW 円筒について, こ の場合のベースにしたエポキシの実験結果に基づく数值 計算結果と，実験結果はよく一致することが確認され た.

\section{参考 文 献}

1）小林繁夫, 石川隆司：日本航空宇宙学会誌，23, 256 (1975) , 319.

2）石川隆司, 小山一夫, 小林繁夫 : 日本航空宇宙学 会誌, 23, 263 (1975)， 678.

3）石川隆司, 小山一夫, 小林繁夫, 湯川 武 : 日本 航空宇宙学会誌, 25, 285 (1977)， 481.

4）シェル株式会社 : 私信.

5）石川隆司，小林繁夫 : 日本航空宇宙学会誌，25, 283 (1977), 394.

6）川端秀雄, 林 哲男, 松田雅敏, 福森健三 : 日本 複合材料学会第 3 回複合材料シンポジウム講演要 旨集 (1977), p. 74 .

7) 石川隆司 : 東京大学大学院工学系研究科学位論文 (1976).

8) S.W. Tsai : NASA CR-71 (1964) 